\title{
The technology acceptance model in the Collaborative learning of Web 2.0, Web 3.0 and Web 4.0: Higher Education case study
}

\section{JUAN CARLOS CHANCUSIG CHISAG ${ }^{1,3}$, NORMA CARMEN GÁLVEZ DÍAZ ${ }^{2}$, FÉLIX MAURICIO MURILLO CALDERÓN ${ }^{3}$, JAVIER GAMBOA CRUZADO ${ }^{1}$, FREDDY EDUARDO QUINCHIMBLA PISUÑA $^{3}$, MIRIAN DORILA IZA CARATE ${ }^{3}$, ALFONSO ROMERO BAYLÓN ${ }^{1}$, OLGA LORENA GONZÁLEZ ORTIZ ${ }^{3}$}

\author{
${ }^{1}$ Universidad Nacional Mayor San Marcos, Lima, PERU. \\ ${ }^{2}$ Universidad Señor de Sipán S.A.C. Lima, PERU. \\ ${ }^{3}$ Universidad Técnica de Cotopaxi, Latacunga, ECUADOR
}

\begin{abstract}
At present, Web 2.0 or Semantic Web is increasingly used to refer to a new state of the Web, while other terms are used such as Ontologies, Web Ontologies, Web Ontology Languages, Social Networks and Social Web, as well as social software. However, many of them are confused with each other and in some cases are taken as the same. These terms are highly linked to Web 2.0, the main objective of the study is to identify how many studies have been carried out on Web 2.0, Web 3.0 and Web 4.0. The methodology used to guide the process of the state of the art is the method of systematic review of the qualitative specialized literature; for this reason, we have chosen to use the guidelines presented for the systematic review of the articles of which 75 were selected from the different scientific journals of great world relevance. The final objective of the academic article is to improve the objective measures used in the various studies of Web 2, Web 3 and Web 4.0. The general conclusion of this study of systematic review of the studies found, is that although Web 4.0 has confirmed to be a very consistent technological resource, it still has limitations that manage to be perceived by other academics as opportunities for future research.

Keywords: collaborative networks, educational institutions, web 2.0 technologies, web 3.0, web 4.0, teaching, Received: February 4, 2020. Revised: October 2, 2020. Accepted: October 6, 2020. Published: October 14, 2020.
\end{abstract}

\section{Introduction}

Recent years have been characterised by technological advances highlighted by the birth of the World Wide Web (WWW) and the development of Web 2.0-based technologies, such as social networking sites, social bookmarking and micro-blogging tools; this has resulted in many opportunities for manufacturing organisations, but also significant challenges, especially in terms of collaboration between employees and projects, and today's companies need to improve communication channels between geographically dispersed and co-located employees and external partners [1] (Aparici, R., \& García, D. (2018 ).

Innovation in technology is happening at a dizzying rate. Hassle-free, open-source applications and services established on the Internet and designed to boost teaching and learning have now been made available to the general public at limited or no cost. These online social networking applications known as Web 2.0 allow people to meet, create, share and broadcast information, thus giving rise to development [2] Barak, Miri (2018). 
Web 2.0 is a platform that allows users to participate directly, in real time, and contribute to the topic under discussion. One of the many features of Web 2.0 technologies is the vast collection of information, such as images, text, data and search indexes. The content available from this platform can be used in various ways, levelling out forms for the development of new pedagogies.

Web 2.0 applications include web-based software and services that enable people to create, share, communicate and collaborate on the web, regardless of geographic, time or technological skill limitations [3] Bosch et al.

Web 2.0, Web 3.0 and Web 4.0 are part of an extremely important advance in education, presenting opportunities for students to improve the quality of their autonomous and collaborative learning, as well as the development of new technological and social skills and competences [4] Buchanan, (2018).

\section{Planning Review}

The process of planning is: a) a systematic review process was developed, in which the search chain was used to define the field of study about Web 2.0, Web 3.0 and Web 4.0 that have been advanced in the universities, then, $b$ ) the research questions were expressed to get the study of the state of the art; and c) the period of systematic search was defined between 2018 and 2020.

\subsection{Search in Scientific Journals}

In this phase, the following were added: a) articles published in recognized scientific journals taking into account the impact factor, both in Spanish and in English, using scientific databases related to ICTs:

- Scopus (http://www.scopus.com)

- IEEE Xplore (http://ieeexplore.ieee.org)

- Elsevier (https://www.elsevier.com)

- Springer Link (https://link.springer.com)

\section{- Google Scholar}

The search strings were generated from the combination of keywords using the AND operator. They were defined as follows (web 2.0 or web 3.0 or web 4.0 and education), for the first search.

The following criteria were proposed for our systematic review

Inclusion criterion 1: Is to filter the articles by the area of Computer Science, a pilot test was carried out, with the intention of improving the search strategy and discarding scientific articles that did not contain sufficient information in relation to proposals for Web 2.0, Web 3.0, Web 4.0 in universities.

Inclusion criterion 2: Articles from recognised specialist journals by date from 2018 to 2020 with the aim of achieving a more up-to-date literature on the subject under review and because the use of ICT in educational projects has been markedly developed in the last three years.

Inclusion criterion 3: Priority will be given to articles, no more than 5 years old, and for references concepts or definitions may be considered older articles by reviewing the impact factor of the indexed journal. That is, the title, abstract, list of key words, conclusions of each article were read to determine whether or not the article met the selection criteria determined.

Inclusion criterion 4: Related articles will be defined that have technical methods and approaches to compare and determine coverage among models of adoption or acceptance of information and communication technology focused on university education, educational institutions, etc. For this, a template was created to obtain the most relevant articles for the systematic review. 


\subsection{Review of the results}

Around 2900 articles were found related to the variables associated with the models of ICT adoption in universities, from which 75 relevant studies were selected, since they contain relevant information to answer the questions asked at the beginning of the research (see Table 1).

Table 1 Systematic Review of Scientific Articles

\begin{tabular}{|c|c|c|c|c|c|c|c|}
\hline Source & $\begin{array}{l}\text { Generic } \\
\text { Search } \\
\text { Chain }\end{array}$ & $\begin{array}{l}\mathbf{N}^{\circ} \\
\text { Result } \\
\text { Base }\end{array}$ & $\begin{array}{l}\mathrm{N}^{\circ} \text { Results } \\
\text { 1st. Iteration } \\
\text { (Criterion } 1 \\
\text { and 2) }\end{array}$ & $\begin{array}{l}N^{\circ} \text { Results } \\
\text { excluded by } \\
\text { object of } \\
\text { study }\end{array}$ & $\begin{array}{l}\mathbf{N}^{\circ} \\
\text { Resultados } \\
\text { incluidos por } \\
\text { objetor de } \\
\text { estudio 2da. } \\
\text { Iteración (3) } \\
\end{array}$ & $\begin{array}{l}\mathrm{N}^{\circ} \\
\text { Relevant } \\
\text { unselected } \\
\text { results }\end{array}$ & $\begin{array}{l}\mathrm{N}^{\circ} \\
\text { Relevant } \\
\text { selected results } \\
\text { 3rd. Iteration } \\
\text { (4) }\end{array}$ \\
\hline Scopus & $\begin{array}{l}\text { (web } 2.0 \text { or } \\
\text { web } 3.0 \text { or } \\
\text { web } 4.0 \text { and } \\
\text { education) }\end{array}$ & $\begin{array}{l}1295 \\
\text { articles }\end{array}$ & $\begin{array}{l}\text { articles } \\
2018(43) \\
2019(38) \\
2020(30)\end{array}$ & 36 articles & $\begin{array}{l}26 \text { articles } \\
2018(9) \\
2019(10) \\
2020(7)\end{array}$ & 20 articles & $\begin{array}{l}11 \text { articles } \\
2018(3) \\
2019(5) \\
2020(3)\end{array}$ \\
\hline IEEE Xplore & $\begin{array}{l}\text { (web } 2.0 \text { or } \\
\text { web } 3.0 \text { or } \\
\text { web } 4.0 \text { and } \\
\text { education) }\end{array}$ & $\begin{array}{l}435 \\
\text { articles }\end{array}$ & $\begin{array}{l}136 \\
\text { Articles } 2018 \\
(25) \\
2019(27) \\
2020(36)\end{array}$ & 85 articles & $\begin{array}{l}23 \text { articles } \\
2018(7) \\
2019(4) \\
2020(12)\end{array}$ & 17 articles & $\begin{array}{l}1 \text { articles } \\
2018(1) \\
2019(0) \\
2020(0)\end{array}$ \\
\hline $\begin{array}{l}\text { Elsevier } \\
\text { Science Direct }\end{array}$ & $\begin{array}{l}\text { (web } 2.0 \text { or } \\
\text { web 3.0 AND } \\
\text { web 4.0 AND } \\
\text { education ) }\end{array}$ & $\begin{array}{l}540 \\
\text { articles }\end{array}$ & $\begin{array}{l}120 \text { articles } \\
2018(10) \\
2019(31) \\
2020(20)\end{array}$ & 29 articles & $\begin{array}{l}17 \quad \text { articles } \\
2018(3) \\
2019(8) \\
2020(6)\end{array}$ & 15 articles & $\begin{array}{l}12 \text { articles } \\
2018(5) \\
2019(2) \\
2020(5)\end{array}$ \\
\hline Springer Link & $\begin{array}{l}\text { (web } 2.0 \text { or } \\
\text { web } 3.0 \text { or } \\
\text { web } 4.0 \text { and } \\
\text { education) }\end{array}$ & $\begin{array}{l}1289 \\
\text { articles }\end{array}$ & $\begin{array}{l}225 \text { articles } \\
2018(35) \\
2019(55) \\
2020(41)\end{array}$ & 148 articles & $\begin{array}{l}36 \text { articles } \\
2018(12) \\
2019(14) \\
2020(10)\end{array}$ & 62 articles & $\begin{array}{l}28 \text { articles } \\
2018(17) \\
2016(8) \\
2020(3)\end{array}$ \\
\hline $\begin{array}{l}\text { Google } \\
\text { Scholar }\end{array}$ & $\begin{array}{l}\text { (web } 2.0 \text { or } \\
\text { web } 3.0 \text { or } \\
\text { web } 4.0 \text { and } \\
\text { education) }\end{array}$ & $\begin{array}{l}189000 \\
\text { articles }\end{array}$ & $\begin{array}{l}86000 \text { articles } \\
\text { in pdf format }\end{array}$ & $\begin{array}{l}16546 \\
\text { articles }\end{array}$ & $\begin{array}{l}129 \text { articles } \\
2018(70) \\
2019(30) \\
2020(29)\end{array}$ & 56 articles & $\begin{array}{l}23 \text { articles } \\
2018(9) \\
2019(6) \\
2020(8)\end{array}$ \\
\hline Total & & 192559 & 86391 & 16844 & 231 & 170 & 75 \\
\hline
\end{tabular}


The criteria for the inclusion of primary studies were essentially oriented in the studies of the following particularities: title, summary, introduction, review of planning, review of process, review of results, outcomes and discussion, conclusions of each research, where it was examined to what extent the projects Web 2.0, Web 3.0 and Web 4.0 in education were evaluated.

In order to establish the effectiveness of the scientific articles, a thorough content analysis was required, taking into account variables such as the level of description of the proposed model, its relationship with the domain of technology acceptance or adoption, and its applicability.

The records of the selected primary studies were distributed in a table with the aim of defining the specific variables of interest and in which the following information was taken into account: code, title, source, country, year, authors, key words, references (if secondary studies exist), main ideas, type of model to be proposed and its real applicability.

Table 2. Template used to store the information of the articles

\begin{tabular}{|c|c|c|c|c|c|c|}
\hline Title in English & \multicolumn{6}{|c|}{$\begin{array}{l}\text { Cyberloafing in IT classrooms: exploring the role of the psycho-social environment in the } \\
\text { classroom, attitude to computers and computing courses, motivation and learning strategies }\end{array}$} \\
\hline Title in Spanish & \multicolumn{6}{|c|}{$\begin{array}{l}\text { Cyberloafing en las aulas de TI: exploración del papel del entorno psicosocial en el aula, actitud } \\
\text { hacia las computadoras y cursos de informática, motivación y estrategias de aprendizaje }\end{array}$} \\
\hline DOI & \multicolumn{6}{|c|}{ - $10.1007 / \mathrm{s} 12528-018-9184-2$} \\
\hline Source & \multicolumn{6}{|c|}{ Springer Science+Business Media, LLC, part of Springer Nature 2018} \\
\hline Sample & \multicolumn{6}{|c|}{607 students } \\
\hline Country & \multicolumn{6}{|l|}{ Turquía } \\
\hline Year & 2018 & Volume & Pages & 23 & $\begin{array}{l}\text { Impact } \\
\text { factor }\end{array}$ & Q1 \\
\hline Authors & \multicolumn{6}{|l|}{ Ramazan Y1lmaz } \\
\hline Website & \multicolumn{2}{|l|}{ Springer } & \multicolumn{2}{|l|}{ Journal } & \multicolumn{2}{|c|}{$\begin{array}{l}\text { Springer } \\
\text { Link }\end{array}$} \\
\hline Key Words & \multicolumn{6}{|c|}{$\begin{array}{l}\text { Cyberloafing, Psycho-social environment, Attitudes, Motivation, Learning strategies, Information } \\
\text { technologies classrooms }\end{array}$} \\
\hline Metodology & \multicolumn{6}{|c|}{ Correlational method } \\
\hline \multicolumn{7}{|c|}{$\begin{array}{l}\text { Conclusions: } \\
\text { Finally, it is shown that the cyberattack behaviors of students are influenced by their perceptions, attitudes and } \\
\text { psychosocial learning strategies. However, the results show that students' cyberattack behaviors are not influenced by } \\
\text { their motivation for courses. }\end{array}$} \\
\hline \multicolumn{7}{|c|}{$\begin{array}{l}\text { Type of model proposed } \\
\text { ICT (Information and Communication Technologies) }\end{array}$} \\
\hline \multicolumn{7}{|c|}{$\begin{array}{l}\text { Application for which the model is used } \\
\text { Software Engineering }\end{array}$} \\
\hline \multicolumn{7}{|c|}{$\begin{array}{l}\text { Bibliography. } \\
\text { Y1lmaz, R., Yurdugül, H. Cyberloafing in TI classroom: exploring the role of the psychosocial } \\
\text { environment in the classroom, attitude towards computers and computer courses, motivation and learning } \\
\text { strategies. J Comput High Educ 30, 530-552 (2018). https://doi.org/10.1007/s12528-018-9184-2 }\end{array}$} \\
\hline
\end{tabular}


The bibliographic references of the selected articles allowed us to investigate a number of research results; we explored specialized databases resulting in 900 consulted articles we kept 75 for analysis of the systematic review.

They were selected using the four inclusion criteria mentioned above; for example, we have a full card of the articles reviewed shown in Table 2.

\section{Results and Discussion}

This section presents the most important results of the systematic review related to Web 2.0, Web 3.0 and Web 4.0 in education within educational institutions of the 75 articles found.
The figure shows the summary of the number of publications per year and per indexed scientific journal, the most relevant database was taken from Scopus with 11 impact studies, followed by Google Scholar with 23 studies, then with 1 IEEE Xplore research, another important database is from Springer Link with 28 academic articles; which represent $98 \%$ of the studies found from the systematic review of the literature on Web 2.0, Web 3.0 and Web 4.0 technologies.

With respect to the years in 2018, 35 researches have been taken, in 201921 articles were found, in 202019 relevant articles have been collected.

Figure 1. Summary of Web 2.0, Web 3.0 and Web 4.0 studies in education and their variants by specialised database.

Table 3 Results of the Journals with Impact Factor

\begin{tabular}{|r|r|r|r|r|r|}
\hline \multicolumn{1}{|l|}{} & Scapus & Springer Link & Google Scholar & Elsevier Science & IEEE XPLORE \\
\hline 2018 & 3 & 17 & 9 & 5 & 1 \\
\hline 2019 & 5 & 8 & 6 & 2 & 0 \\
\hline 2020 & 3 & 3 & 8 & 5 & 0 \\
\hline \multirow{2}{*}{ Total } & 11 & 28 & 23 & 12 & 1 \\
\hline
\end{tabular}

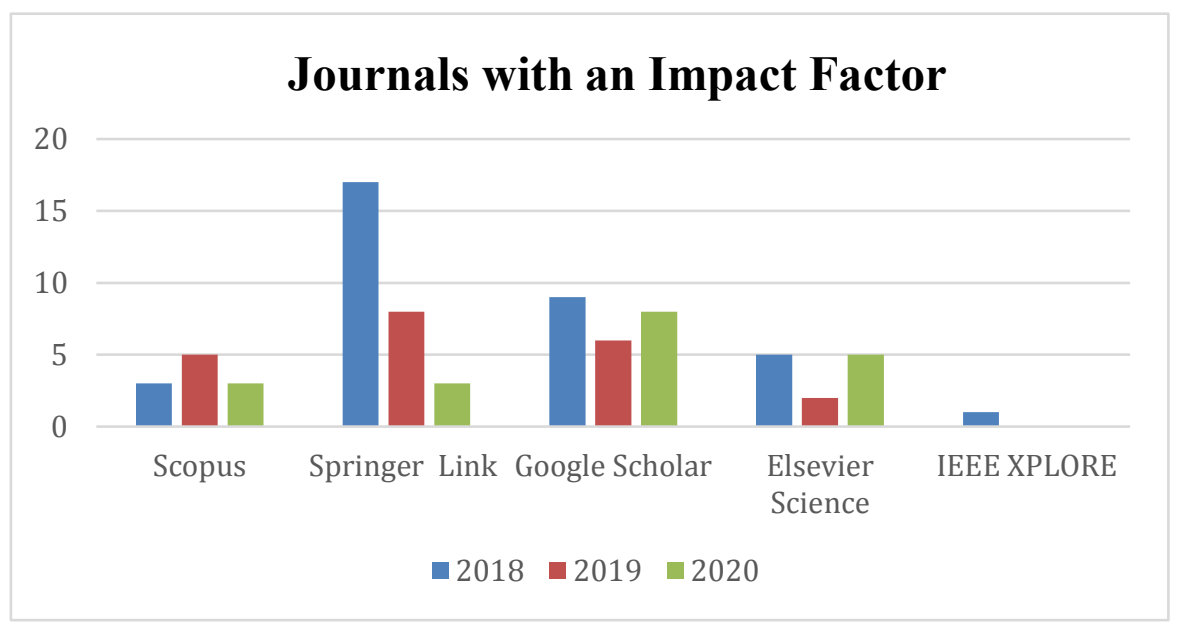


The Figure shows the distribution of the 75 articles by type of study, the studies found define the following authors: [5] Calva, José Luis, (2017) who tries to understand the quality and impact of content in collaborative investment platforms, through empirical analysis; [6] Carlisle, D.L., (2018), describes application-level caching in web applications through an empirical study; [8] JiménezSaavedra, (2018), develops a process model, a critical review of blended-based computer education; [9] Juan Carlos Chancusig Chisag and Javier Arturo Gamboa Cruzado, (2020), whose main aim of the article is to analyse evidence-based pedagogical approaches related to the use of Web 2 technologies. 0, Web 3.0 in virtual higher education environments; [10] López-Gil, M. \& BernalBravo, C. (2019), provide a review of the theoretical bases and research on the uses of Web 2.0 applications (blogs, wikis, collaborative documents and conceptual mapping, video sharing applications, microblogging, social networking sites and social bookmarking for collaborative learning); [11] Brazilian Ministry of Foreign Affairs. (2018), uses multi-channel online learning resources (OLR) in learning activities that benefit extensively from traditional learning based on collaborative learning that emphasises widespread learning anywhere, anytime; [7] R. Chacón (2014), in this reflection, we discuss the connectivist conception of learning in Web 2.0 environments, which points to the pedagogy of what are known as CMOOCs (massively open online courses); [12] Moscoso, R. V. (2018), explains the integration of Web 2.0 technologies in face recognition to help produce, store and share content in a higher education course, empirically explains the forms of effective collaboration skills training for students based on the use of Web TC; [13] Sarrab, M., Al-Shihi, H., Al-Manthari, B. et al. Toward. (2018), explain what the usability of mobile applications is: a literature review and the rationale for a new mode of usability in education, [14] Batova Marina Mikhailovna, Baranova Irina Vyacheslavovna. (2019), the report proposed a model of the intellectual space, reflecting the mechanisms of knowledge representation on the processes of innovative modernisation. Knowledge was systematised in thematic areas such as mathematical modelling, innovation and project management, and organisational design. In order to systematize knowledge in the field of project management, a database of foreign and Russian information systems on the market has been created, which are used to solve problems of However, the software products included in the knowledge base do not fully reflect the design. The knowledge

base contains information on the technological and organisational details of innovative modernisation, as well as the details of investment capital formation. The analysis showed that a significant drawback of the software systems included in the database is the low level of detail of the economic and mathematical models that form the basis of the software product.

Table 4. Articles by type of study

\begin{tabular}{|l|r|}
\hline Kind of study & $\mathbf{N}^{\circ}$ of studies (75) \\
\hline Laboratory Study & 1 \\
\hline Field investigation & 74 \\
\hline TOTAL & $\mathbf{7 5}$ \\
\hline
\end{tabular}


Table 4 shows the distribution of the 75 academic articles in the 5 scientific journals in a total of 74 in the different universities of higher education, thus validating the studies found worldwide.

Table 5. Studies found in the different countries of the world

\begin{tabular}{|l|r|}
\hline Country & $\begin{array}{l}\text { N } \\
\text { studies }\end{array}$ \\
\hline Spain & 18 \\
\hline México & 10 \\
\hline Colombia & 6 \\
\hline United States & 5 \\
\hline Australia & 4 \\
\hline China & 3 \\
\hline Ecuador & 3 \\
\hline Brazil & 2 \\
\hline British & 2 \\
\hline Argentina & 2 \\
\hline Germany & 2 \\
\hline Australia- China & 1 \\
\hline Costa Rica & 1 \\
\hline France & 1 \\
\hline India & 1 \\
\hline Indonesia & 1 \\
\hline Irak & 1 \\
\hline Irán & 1 \\
\hline Malasia & 1 \\
\hline Norway & 1 \\
\hline New Zeland & 1 \\
\hline Omán & 1 \\
\hline Perú & 1 \\
\hline Poland & 1 \\
\hline Portugal & 1 \\
\hline Republic of Korea & 1 \\
\hline Street New York & 1 \\
\hline Sweden & 1 \\
\hline Turkey & 1 \\
\hline TOTAL & 1 \\
\hline & 1 \\
\hline
\end{tabular}

mentioned above, they have published 1 article on laboratory studies and field research

Table 5 shows the distribution of the 75 articles per country where the countries with more academic articles prevail, such as Spain, Mexico, Colombia, United States, Australia, China, Ecuador being the precursors of the studies carried out to improve the teaching and learning process.

\section{Conclusions}

- In the last two decades we have witnessed the spontaneous emergence of a culture of participation on a global scale which, although still very superficial and scarcely significant when it comes to varying the structures of communicational power of previous stages, has served to intuit the potential of cognitive intelligence and the power of communication between equals, where they are made public from everyday aspects to political, educational or social manifestations.

- Throughout this work, an attempt has been made to know and analyse the digital competences of the university students of the Degrees in Education of the University of Cadiz. These skills will be in constant transformation as will the technologies themselves and the needs and educational possibilities that derive from them. The presence of technologies has transformed every socio-educational area, in the sources and agents of knowledge and the ways of understanding, building and disseminating knowledge. This panorama requires the development of certain skills in students to face the dizzying and deep challenges posed by the possibilities of Web 2.0, 3.0 and 4.0 applications, interacting reciprocally with their educational practices to develop, evolve and improve educational processes.

- Currently, students' demands respond to communication needs using tools such as 
mobile phones, which have an increasing number of applications. If we teachers are familiar with them, we can make them useful and not just limited to children's games. For this reason, there is a lack of synchronisation between what the student needs and what the teacher provides. If we want to develop skills so that students can develop effectively in the time that teachers have to live, we cannot turn our backs on the new technologies used in education and the construction of new learning.

- The research presented contributes to the development of learning using Web 2.0, Web 3.0 and Web 4.0 technologies and its main objective is to improve the effectiveness of education, by designing personalized activities and expanding the selection of ICT tools to support universities in the teaching-learning process in universities.

- A systematic review was carried out in the main scientific journals with an impact factor such as Scopus, IEEE Access, Springer, Elsevier Science Direct, Google Scholar from 2018 to 2020 of published works on technologies 2.0, 3.0 and 4.0, finding a total of 75 studies carried out. In the different countries of the world, each one shows the scientific advances they have developed and the contributions they have made to science.

\section{References}

[1] Aparici, R., \& García , D. (2018 ). Communicating and educating in the world to come. Spain: 2a Applied.

[2] Barak, Miri. (2018) Transition from traditional to ICT-enhanced learning environments in undergraduate chemistry courses, in Computer Science and Education,(48),pp.30-43.

[3] Bosch et al. 2008, Blended-learning Enhancing performance in sales negotiations, paper presented at 10th IASTED International Conference on Computers and Advanced Technology in Education.
[4] Buchanan, 2018, Federalism as an Ideal Political Order and an Objective for Constitutional Reform.Publius, pp. 19-27.

[5] Calva, José Luis, "Determinantes de la competitividad nacional", in Edu-cación, ciencia, tecnología y competitividad, unam, Miguel Ángel Porrúa, (2018) Consejo Nacional de Población, "La situación actual de los jóvenes en México", Conapo México, 2017.

[6] Carlisle, D.L., Weaver, G.C. STEM education centers: catalyzing the improvement of undergraduate STEM education. IJ STEM Ed $\quad 5, \quad 47 \quad$ (2018). https://doi.org/10.1186/s40594-018-0143-2

[7] R. Chacón, "El aprendizaje de idiomas mediante MOOCs," VI Jornadas de Redes de Investigación en Innovación docente de la UNED, 2014.

[8] Jiménez-Saavedra, 2018. Sergio-Aurelio Jiménez-Saavedra. Educational technology: training fields and differential profile. Revista Iberoamericana de Educación Superior (RIES), pp. 125. Apoyo a la Calidad Educativa, 2008.Cerrando el Círculo, Más allá de la Evaluación, Cuarto Congreso Internacional de Calidad Educativa, CDROM, (2018).

[9] Juan Carlos Chancusig Chisag and Javier Arturo Gamboa Cruzado, Results Validation about the Adoption Model of Information and Communication Technologies Applied to the Technical University of Cotopaxi. WSEAS Transactions on Environment and Development, pp.158-171, Volume 16, 2020.

[10] López-Gil, M. \& Bernal-Bravo, C.(2019). The profile of the teaching staff in the Network Society: reflections on the digital competences of men and women in Education from the University of CadizInternational Journal of Educational Research and Innovation (IJERI), 11, 83-100ISSN: 2386-4303 
[11] Brazilian Ministry of Foreign Affairs. (2018) Innovation policies in Brazil in the United States: a search for competitiveness opportunities for diplomatic action, Obtained. https://www.elsevier.es/es-revista-revistaeducacion-superior-216-articulo-cienciaacademica-intelectuales-el-trabajoS0185276015000679? referer=buscador.

[12] Moscoso, R. V. (2018 ). Use of ICT for autonomous management of student learning. Lima-Peru: IEN ${ }^{\circ} 50247$.
[13] Sarrab, M., Al-Shihi, H., Al-Manthari, B. et al. Toward Educational Requirements Model for Mobile Learning Development and Adoption in Higher Education. TechTrends 62 , 635-646 (2018). https://doi.org/10.1007/s1 1528-018-0331-4.

[14] Batova Marina Mikhailovna, Baranova Irina Vyacheslavovna. Knowledge Management in Information Technologies in the System of Interaction of Educational and Scientific-Productive Structures WSEAS Transaction on Business and Economics, pp. 545-551- Volume 16, 2019.

\section{Creative Commons Attribution License 4.0} (Attribution 4.0 International, CC BY 4.0)

This article is published under the terms of the Creative Commons Attribution License 4.0

https://creativecommons.org/licenses/by/4.0/deed.en_US 